\title{
Development and Validation of First Order Derivative Spectrophotometric Methods for the Assay of Prucalopride Succinate
}

\section{Goutham Dev Ashish Bojja and Mukthinuthalapati Mathrusri Annapurna*}

Gandhi Institute of Technology and Management (Deemed to be) University, GITAM Institute of Pharmacy, Visakhapatnam, India

*Corresponding Author: Mukthinuthalapati Mathrusri Annapurna, GITAM Institute of Pharmacy, GITAM (Deemed to be) University, Visakhapatnam, India.
Received: April 19, 2020

Published: May 04, 2020

(C) All rights are reserved by Goutham Dev

Ashish Bojja and Mukthinuthalapati

Mathrusri Annapurna

\begin{abstract}
Prucalopride succinate is an orally active and selective, high affinity 5-HT4 receptor agonist which targets the impaired motility associated with chronic constipation and thus normalizing bowel movements. It is used for the treatment of chronic constipation. Four new first order derivative spectrophotometric methods have been developed for the assay of Prucalopride succinate in pharmaceutical formulations. Prucalopride succinate was estimated using reagents such as $0.1 \mathrm{~N} \mathrm{HCl} \mathrm{(Method} \mathrm{A),} \mathrm{phosphate} \mathrm{buffer} \mathrm{(pH} \mathrm{2.0)}$ (Method B), acetate buffer (pH 5.0) (Method C) and 0.1N NaOH (Method D). Beer-Lambert's law was obeyed over the concentration range $5-60 \mu \mathrm{g} / \mathrm{ml}$ in Method A and B and $5-50 \mu \mathrm{g} / \mathrm{ml}$ in Method C and D. The methods were found to be simple, precise, accurate, economical and the methods were validated as per ICH guidelines. These methods can be successfully applied for the determination of Ketorolac tromethamine in pharmaceutical dosage forms.

Keywords: First Derivative Spectroscopy; Prucalopride Succinate; Spectroscopy; Phosphate Buffer; Acetate Buffer; Sodium Hydroxide; HCl; Validation
\end{abstract}

\section{Introduction}

Prucalopride is used to treat chronic constipation and it also facilitates cholinergic and excitatory non-adrenergic, noncholinergic neurotransmission [1,2]. Prucalopride (Figure 1) stimulates colonic mass movements and provides the main propulsive force for defecation. Prucalopride succinate $\left(\mathrm{C}_{22} \mathrm{H}_{32} \mathrm{ClN}_{3} \mathrm{O}_{7}\right.$; Mol. Wt. $485.96 \mathrm{~g} / \mathrm{mol}$ ) is benzo furan carboxamide butanedioic acid derivative. Prucalopride acts via a systemic mechanism initiating high amplitude propagated contractions in the colon [3]. Prucalopride enhances colonic propulsion and accelerates right colon emptying. Prucalopride also accelerates gastric emptying and small bowel transit [4-6].

Sun Z., et al. UHPLC-MS/MS method in rat plasma [7] for the quantitation of Prucalopride and Mahamuni., et al. separated and characterised the stress degradation products and process impurities of Prucalopride by LC-QTOF-MS/MS [8]. Virag., et al. established HPLC [9] and Buiter., et al. evaluated the preclinical evaluation of [11C] Prucalopride as a potential agonist PET ligand for the 5- $\mathrm{HT}_{4}$ receptor using radiosynthesis [10] At present four new UV spectrophotometric methods have been proposed for the determination of Prucalopride succinate in pharmaceutical formulations and the method was validated as per ICH guidelines [11].

\section{Materials and Methods}

Prucalopride succinate is available as film coated tablets (2 mg) with brand name RESOLOR (2 mg) (Shire Biotech India Pvt Ltd) and PRUEASE ${ }^{\mathrm{TM}}$ (SUN Pharma), PRUCAPLA (Cipla Ltd.). Prucalo-

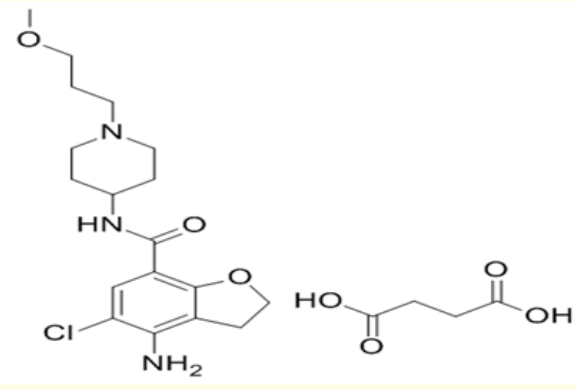

Figure 1: Structure of prucalopride succinate.

pride succinate was obtained as a gift sample from SYMED LABS Ltd (India). Double beam spectrophotometer (SHIMADZU Model No. UV - 1800) with quartz cells was used for the present study. All the solutions were scanned at $200-400 \mathrm{~nm}$ range. Reagents such as $0.1 \mathrm{~N} \mathrm{HCl} \mathrm{(Method} \mathrm{A),} \mathrm{phosphate} \mathrm{buffer} \mathrm{(} \mathrm{pH} 2.0$ ) (Method B), acetate buffer ( $\mathrm{pH}$ 5.0) (Method C) and 0.1N NaOH (Method D) were prepared as per IP 2010.

\section{Method validation}

\section{Procedure}

Stock solution of Prucalopride succinate was prepared by dissolving $25 \mathrm{mg}$ of drug in a $25 \mathrm{ml}$ volumetric flask in methanol (1000 $\mu \mathrm{g} / \mathrm{ml}$ ) and diluted solutions were prepared from the stock solution with $0.1 \mathrm{~N} \mathrm{HCl}$ (Method A), phosphate buffer (pH 2.0) (Method B), acetate buffer (pH 5.0) (Method C) and 0.1N NaOH (Method D) as per the requirement. 
A series of Prucalopride succinate solutions $(5-60 \mu \mathrm{g} / \mathrm{ml})$ were prepared using $0.1 \mathrm{~N} \mathrm{HCl}($ Method A), phosphate buffer $\mathrm{pH} 2$ (Method II) and (5 - $50 \mu \mathrm{g} / \mathrm{ml})$ using acetate buffer pH 5.0 (Method III) and $\mathrm{NaOH}$ (Method IV) and scanned (200 - $400 \mathrm{~nm}$ ) against their reagent blank. The individual zero order spectra of Prucalopride succinate so obtained in the above reagents were transferred into the first order derivative spectra with the help of inbuilt software of the instrument, SHIMADZU Model No. UV - 1800 double beam spectrophotometer. The resultant first order derivative spectrum has shown both maxima and minima in all the four reagents and therefore the amplitude was chosen for the construction of calibration curve and other calculation purpose for all the methods. Calibration curves were drawn by taking the concentration on the $\mathrm{x}$-axis and the corresponding amplitude on the $\mathrm{y}$-axis for all the methods.

Precision was studied by measuring the derivative absorbance (amplitude) of 6 solutions of the same concentration $(n=6)$ for all the methods and there by mean, standard deviation and relative standard deviation were calculated. Accuracy was studied by spiking the formulation solution of a fixed concentration with pure drug solution $(50 \%, 100 \%$ and $150 \%)$ by standard addition method and there by percentage recovery and relative standard deviation were calculated.

\section{Assay of prucalopride succinate tablets}

20 tablets of Prucalopride succinate of two different brands were procured from the local pharmacy store and tablet powder consisting of $25 \mathrm{mg}$ of Prucalopride succinate was accurately weighed and extracted with methanol. The contents were sonicated well, filtered and dilutions were made with respective buffers for Method A, B, C and D and assay was performed.

\section{Results and Discussion}

Prucalopride succinate assay was performed in reagents such as $0.1 \mathrm{~N} \mathrm{HCl}$ (Method A), phosphate buffer ( $\mathrm{pH}$ 2.0) (Method B), acetate buffer ( $\mathrm{pH}$ 5.0) (Method C) and 0.1N NaOH (Method D) using first derivative spectrophotometric technique in the present study. Table 1 shows the analytical details of the present proposed methods with the previously published spectrophotometric methods in the literature.

The first order derivative absorption spectra of Prucalopride succinate were shown in figure 2 and the calibration curves were shown in figure 3. Beer-Lambert's law was obeyed over the concentration range 5-60 $\mu \mathrm{g} / \mathrm{ml}$ for Method A and B and $5-50 \mu \mathrm{g} /$ $\mathrm{ml}$ for Method C and D (Table 2). The calibration curves obtained were shown in figure 3. All the four methods were precise (Table 3) and accurate (Table 4) as the \%RSD was found to be less than 2 . The assay was performed for two different brands of Prucalopride succinate available in the Indian market and percentage of purity was calculated from the regression equations obtained from the calibration curves and the results were shown in table 5 and no interference of excipients was observed.

\begin{tabular}{|c|c|c|c|}
\hline Method & $\begin{array}{l}\text { Mobile Phase/ } \\
\text { Reagents }\end{array}$ & $\begin{array}{l}\text { Linearity } \\
(\mu \mathrm{g} / \mathrm{mL})\end{array}$ & Ref \\
\hline $\begin{array}{l}\text { UHPLC-MS/ } \\
\text { MS }\end{array}$ & $\begin{array}{l}\text { Acetonitrile: } 0.1 \% \\
\text { Formic acid }\end{array}$ & $\begin{array}{cc}1.1 & 100 \mathrm{x} \\
10^{-3} \mathrm{ng} / \\
\mathrm{mL}\end{array}$ & $\begin{array}{c}7 \\
\text { Rat } \\
\text { Plasma }\end{array}$ \\
\hline $\begin{array}{l}\text { LC-QTOF-MS/ } \\
\text { MS }\end{array}$ & $\begin{array}{c}20 \mathrm{mM} \text { Ammo- } \\
\text { nium bicarbonate } \\
\text { buffer and aceto- } \\
\text { nitrile: methanol } \\
(80: 20 \mathrm{v} / \mathrm{v})\end{array}$ & - & $\begin{array}{c}8 \\
\text { Impurities }\end{array}$ \\
\hline RP-HPLC & $\begin{array}{l}10 \mathrm{mM} \text { Potassium } \\
\text { dihydrogen phos- } \\
\text { phate buffer (pH } \\
\text { 2.0): methanol } \\
(50: 50)\end{array}$ & $50-150$ & 9 \\
\hline
\end{tabular}

Table 1: Review of prucalopride succinate.

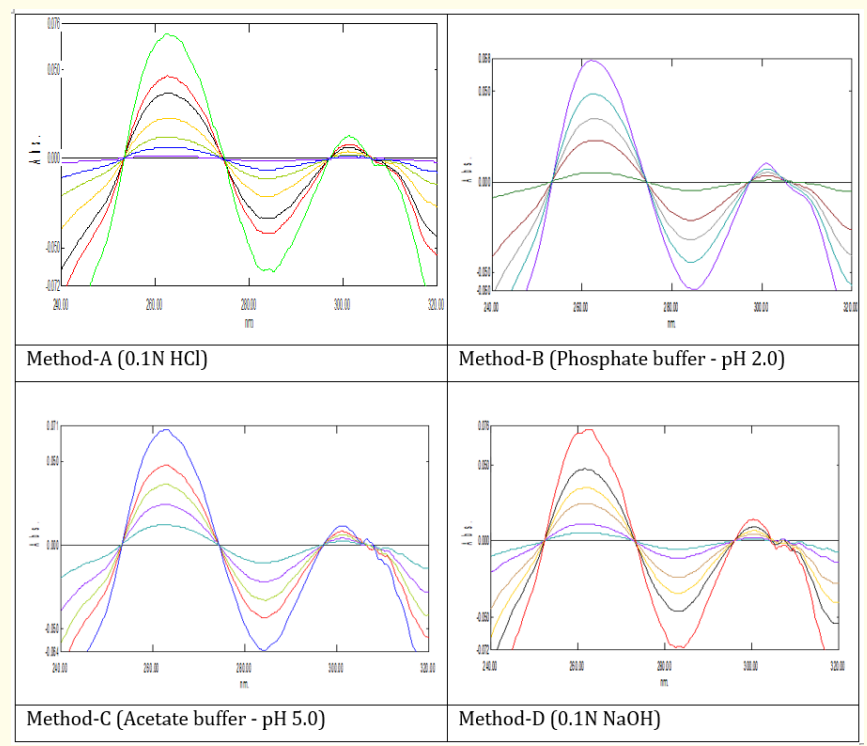

Figure 2: Overlay first order derivative spectra of prucalopride succinate $\left(D_{1}\right)$.

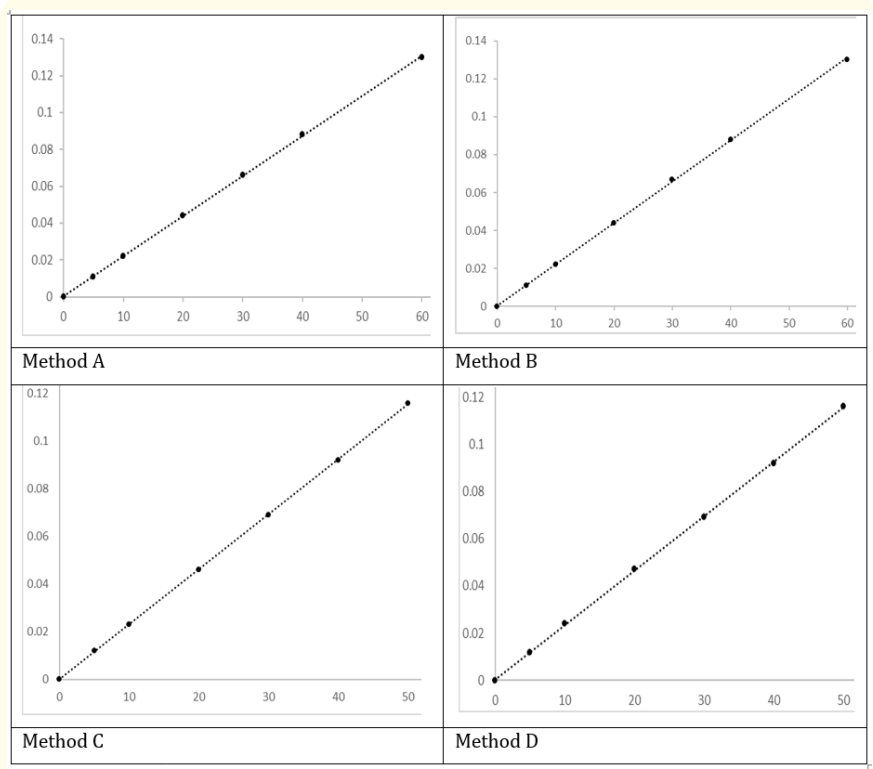

Figure 3: Calibration curves of prucalopride succinate (First derivative spectroscopy). 


\begin{tabular}{|c|c|c|c|c|c|c|}
\hline \multirow{2}{*}{$\begin{array}{c}\text { Conc. } \\
(\mu \mathrm{g} / \mathrm{ml})\end{array}$} & \multicolumn{3}{|c|}{ Method A } & \multicolumn{3}{|c|}{ Method B } \\
\hline & *Maxima & *Minima & ${ }^{*}$ Amplitude & ${ }^{*}$ Maxima & *Minima & *Amplitude \\
\hline 5 & 0.006 & 0.005 & 0.011 & 0.006 & 0.005 & 0.011 \\
\hline 10 & 0.012 & 0.011 & 0.023 & 0.012 & 0.010 & 0.022 \\
\hline 20 & 0.024 & 0.021 & 0.043 & 0.024 & 0.020 & 0.044 \\
\hline 30 & 0.036 & 0.030 & 0.066 & 0.035 & 0.032 & 0.067 \\
\hline 40 & 0.048 & 0.040 & 0.088 & 0.048 & 0.043 & 0.091 \\
\hline 60 & 0.070 & 0.062 & 0.132 & 0.068 & 0.059 & 0.127 \\
\hline \multirow{2}{*}{$\begin{array}{c}\text { Conc. } \\
(\mu \mathrm{g} / \mathrm{ml})\end{array}$} & \multicolumn{3}{|c|}{ Method C } & \multicolumn{3}{|c|}{ Method D } \\
\hline & ${ }^{*}$ Maxima & *Minima & *Amplitude & $*$ Maxima & *Minima & *Amplitude \\
\hline 5 & 0.006 & 0.006 & 0.012 & 0.006 & 0.006 & 0.012 \\
\hline 10 & 0.012 & 0.011 & 0.023 & 0.012 & 0.012 & 0.024 \\
\hline 20 & 0.024 & 0.021 & 0.045 & 0.024 & 0.022 & 0.042 \\
\hline 30 & 0.036 & 0.033 & 0.069 & 0.036 & 0.032 & 0.068 \\
\hline 40 & 0.046 & 0.045 & 0.091 & 0.046 & 0.046 & 0.092 \\
\hline 50 & 0.058 & 0.064 & 0.112 & 0.056 & 0.060 & 0.116 \\
\hline
\end{tabular}

Table 2: Linearity (First derivative spectroscopy) (Max: Maxima; Min: Minima). *Mean of three replicates.

\begin{tabular}{|c|c|c|c|c|}
\hline \multirow{2}{*}{$\begin{array}{c}\text { Conc. } \\
(\boldsymbol{\mu g} / \mathbf{m l})\end{array}$} & \multicolumn{4}{|c|}{ Statistical parameters: Mean \pm SD (\% RSD) } \\
\cline { 2 - 5 } & Method A & Method B & Method C & Method D \\
\hline 10 & $0.023 \pm 0.0368$ & $0.022 \pm 0.0462$ & $0.023 \pm 0.0414$ & $0.024 \pm 0.0744$ \\
\hline 10 & $(0.016)$ & $(0.021)$ & $(0.018)$ & $(0.031)$ \\
\hline 10 & & & & \\
\hline 10 & & & & \\
\hline 10 & & & & \\
\hline 10 & & & & \\
\hline
\end{tabular}

Table 3: Precision study of prucalopride succinate.

*Mean of three replicates.

\begin{tabular}{|c|c|c|c|c|c|c|}
\hline \multirow{2}{*}{$\begin{array}{l}\text { Spiked } \\
\text { Conc. }\end{array}$} & \multirow[t]{2}{*}{ Formulation } & \multirow{2}{*}{$\begin{array}{l}\text { Total } \\
\text { Conc. }\end{array}$} & \multicolumn{4}{|c|}{ Conc. obtained (\% Recovery) } \\
\hline & & & Method A & Method B & Method C & Method D \\
\hline 5 & 10 & 15 & 14.89 (99.27) & $14.91(99.4)$ & 14.99 & 14.96 \\
\hline 5 & 10 & 15 & & & (99.93) & (99.73) \\
\hline 5 & 10 & 15 & & & & \\
\hline 10 & 10 & 20 & 19.92 & 19.97 & $19.94(99.7)$ & $19.84(99.2)$ \\
\hline 10 & 10 & 20 & & (99.85) & & \\
\hline 10 & 10 & 20 & & & & \\
\hline 15 & 10 & 25 & $24.97(99.88)$ & 24.92 & 24.93 & 24.96 \\
\hline 15 & 10 & 25 & & (99.68) & $(99.72)$ & $(99.84)$ \\
\hline 15 & 10 & 25 & & & & \\
\hline
\end{tabular}

Table 4: Accuracy study of prucalopride succinate (Conc. $\mu \mathrm{g} / \mathrm{ml}$ ).

*Mean of three replicates.

\begin{tabular}{|l|c|c|c|c|c|c|c|c|}
\hline \multirow{2}{*}{ Brand } & \multicolumn{2}{|c|}{ Method A } & \multicolumn{2}{c|}{ Method B } & \multicolumn{2}{c|}{ Method C } & \multicolumn{2}{c|}{ Method D } \\
\cline { 2 - 10 } & $\begin{array}{c}\text { Observed } \\
\text { amount (mg) }\end{array}$ & $\begin{array}{c}\text { \% } \\
\text { Recovery }\end{array}$ & $\begin{array}{c}\text { Observed } \\
\text { amount (mg) }\end{array}$ & $\begin{array}{c}\text { \% } \\
\text { Recovery }\end{array}$ & $\begin{array}{c}\text { Observed } \\
\text { amount (mg) }\end{array}$ & $\begin{array}{c}\text { \% } \\
\text { Recovery }\end{array}$ & $\begin{array}{c}\text { Observed } \\
\text { amount (mg) }\end{array}$ & $\begin{array}{c}\text { \% } \\
\text { Recovery }\end{array}$ \\
\hline I & 1.987 & 99.35 & 1.979 & 98.95 & 1.972 & 98.60 & 1.991 & 99.55 \\
\hline II & 1.983 & 99.15 & 1.981 & 99.05 & 1.978 & 98.9 & 1.989 & 99.45 \\
\hline
\end{tabular}

Table 5: Assay of prucalopride succinate (Label claim: $2 \mathrm{mg}$ ).

* Mean of three replicates. 


\section{Conclusion}

The four validated first order derivative spectrophotometric methods so developed are simple, precise, accurate and economical. The methods can be successfully applied for the determination of Prucalopride succinate in pharmaceutical dosage forms.

\section{Acknowledgment}

The authors are grateful to M/s GITAM (Deemed to be University), Visakhapatnam for providing the research facilities and to SYMED LABS Ltd (India) for providing the gift samples of Prucalopride succinate.

\section{Bibliography}

1. Leclere PG., et al. "5-HT4 receptors located on cholinergic nerves in human colon circular muscle". Neurogastroenterology and Motility 17.3 (2005): 366-375.

2. Joslyn A., et al. "Prucalopride is safe and generally well tolerated in elderly patients with chronic constipation". American Journal of Gastroenterology 95.9 (2000): 2537-2538.

3. De Schryver AM., et al. "The effects of the specific 5HT(4) receptor agonist, prucalopride, on colonic motility in healthy volunteers". Alimentary Pharmacology and Therapeutics 16.3 (2002): 603-612.

4. Emmanuel AV., et al. "Effect of a novel prokinetic drug R093877 on gastrointestinal transit in healthy volunteers". Gut 42.4 (1998): 511-516.

5. Bouras EP., et al. "Selective stimulation of colonic transit by the benzofuran 5-HT4 agonist, Prucalopride in healthy humans". Gut 44.5 (1999): 482-486.

6. Bouras EP., et al. "Prucalopride accelerates gastrointestinal and colonic transit in patients with constipation". Gastroenterology 120.2 (2001): 354-360.

7. Sun Z., et al. "Development and validation of a sensitive UHPLC-MS/MS method for quantitation of Prucalopride in rat plasma and its application to pharmacokinetics study". Journal of Chromatography. B, Analytical Technologies in the Biomedical and Life Sciences 1033-1034 (2016): 328-333.

8. Mahamuni BS., et al. "Selective separation and characterisation of stress degradation products and process impurities of Prucalopride succinate by LC-QTOF-MS/MS". Journal of Pharmaceutical and Biomedical Analysis 125 (2016): 219-228.

9. Virag Gophane and Ravi AT. "Development, validation and stability indicating rp-hplc method for estimation of Prucalopride in pharmaceutical formulation". Inventi Rapid: Pharm Analysis and Quality Assurance 3 (2016): 1-8.

10. Buiter HJ., et al. "Radiosynthesis and preclinical evaluation of [11C] Prucalopride as a potential agonist PET ligand for the 5-HT4 receptor". EJNMMI Research 3.1 (2013): 24.

11. ICH Q2 [R1] validation of analytical procedures: Text and Methodology: November 2005.

\section{Assets from publication with us}

- Prompt Acknowledgement after receiving the article

- Thorough Double blinded peer review

- Rapid Publication

- Issue of Publication Certificate

- High visibility of your Published work

Website: www.actascientific.com/

Submit Article: www.actascientific.com/submission.php Email us: editor@actascientific.com

Contact us: +919182824667 